in vivo 36 : $94-102(2022)$

doi: $10.21873 /$ invivo. 12680

\title{
Telomerase Reverse Transcriptase Promoter Mutations in Human Hepatobiliary, Pancreatic and Gastrointestinal Cancer Cell Lines
}

\author{
MASAHIRO HIRATA ${ }^{1}$, KOJI FUJITA ${ }^{1}$, SHINTARO FUJIHARA ${ }^{1}$, TAKAAKI MIZUO ${ }^{1}$, \\ RYOTA NAKABAYASHI ${ }^{1}$, TOSHIAKI KONO ${ }^{1}$, DAISUKE NAMIMA ${ }^{1}$, NAOKI FUJTA ${ }^{1}$, \\ HIROKI YAMANA ${ }^{1}$, HIDEKI KAMADA ${ }^{1}$, JOJI TANI ${ }^{1}$, HIDEKI KOBARA $^{1}$, KUNIHIKO TSUTSUI $^{1}$, \\ YOKO MATSUDA ${ }^{2}$, MASAFUMI ONO ${ }^{1}$ and TSUTOMU MASAKI ${ }^{1}$ \\ ${ }^{1}$ Department of Gastroenterology and Neurology, Kagawa University, Kagawa, Japan; \\ ${ }^{2}$ Department of Pathology and Host-Defense, Faculty of Medicine, Kagawa University, Kagawa, Japan
}

\begin{abstract}
Background/Aim: The promoter region of the telomerase reverse transcriptase (TERT) gene is a regulatory element capable of affecting TERT expression, telomerase activity, and telomerase length. Mutations within the TERT promoter region are the most common mutations in many cancers. In this study, we characterized the TERT promoter mutation status in hepatobiliary, pancreatic, and gastrointestinal cancer cell lines. Materials and Methods: TERT promoter mutation status was assessed by digital PCR in 12 liver cancer, 5 cholangiocarcinoma (CCA), 12 pancreatic cancer, 17 gastrointestinal cancer, and 3 healthy control cell lines. Results: The C228T promoter mutation was detected in 9 liver cancer lines, and the C250T TERT mutation was detected in 1 oesophageal squamous cell carcinoma line. Conclusion: The C228T promoter mutation is specific to liver cancer cell lines among various gastrointestinal cancer cell lines. These data will contribute to future research on the tumorigenic mechanisms and clinical use of digital PCR to detect mutations.
\end{abstract}

Telomerase is a ribonucleoprotein complex that maintains genomic stability and telomere length at the end of chromosomes and plays a key role in cellular immortality and tumourigenesis (1). Telomerase is estimated to be over-expressed in $85 \%-90 \%$

This article is freely accessible online.

Correspondence to: Tsutomu Masaki, MD, Ph.D., Department of Gastroenterology and Neurology, Kagawa University Faculty of Medicine, Graduate School of Medicine, 1750-1 Ikenobe, Miki-cho, Kita-gun, Kagawa 761-0793, Japan. Tel: +81 878912156, Fax: +81 878912158,e-mail: tmasaki@med.kagawa-u.ac.jp

Key Words: TERT, telomerase, hepatobiliary, gastrointestinal, cancer, digital PCR, TERT promoter C228T, TERT promoter C250T. of all human malignancies (2). The catalytic subunit of telomerase is telomerase reverse transcriptase (TERT), which is transcriptionally activated in germline, stem, and cancer cells but silenced in somatic cells (3). Therefore, TERT is a gatekeeper for cellular immortalization while maintaining chromosomal integrity. Several studies have demonstrated the importance of transcriptional, post-transcriptional, and post-translational TERT regulation, which may play a role in cancer development (4-7). In particular, TERT promoter mutations are the most common mutations in many types of cancer (8).

Two particularly common TERT promoter mutations lead to increased telomerase expression and consist of cytosine to thymine transitions located -124 and -146 base pairs upstream of the TERT translational start codon (chromosome 5:1295228 and chromosome 5:1295250, termed C228T and C250T here, respectively) $(9,10)$. Together, these mutations have been identified in $20 \%-82 \%$ of hepatocellular carcinomas (HCC) (11) as well as in a significant percentage of other malignancies, including melanoma, glioma, urothelial cancer, and basal cell carcinoma $(12,13)$. Several clinical studies have revealed that the presence of TERT promoter mutations was closely correlated with poor prognosis in patients with solid tumours, such as lung and breast cancer (14).

The occurrence of TERT promoter mutations in liver carcinogenesis has been observed in precancerous lesions, with the prevalence of mutations gradually increasing in conjunction with the degree of dysplasia. These findings indicate that TERT promoter mutations are strongly associated with the gradual transformation of precancerous lesions from dysplastic nodules to malignant hepatocellular carcinoma (11). Moreover, the presence of a TERT C228T promoter mutation in the plasma of HCC patients was associated with a worse prognosis (15). TERT promoter mutations are observed in other cancers, such as cholangiocarcinoma (CCA) (11) and oesophageal squamous 
cell carcinoma (16), but at a lower frequency. Despite the importance of TERT mutations in liver and other cancers, no studies have reported on the presence or absence of TERT promoter point mutations in various types of hepatobiliary, pancreatic, and gastrointestinal cancer cell lines using digital PCR (dPCR). In this study, we used dPCR to characterize C228T and C250T TERT promoter mutations in 46 cancer cell lines and three healthy control cell lines. Although the presence or absence of TERT promoter point mutations has been determined for some gastrointestinal cancers using realtime PCR and Sanger sequencing, there has been no comprehensive analysis of gastrointestinal cancers by dPCR. Therefore, we used $\mathrm{dPCR}$ as a first step to understand potential differences in mutation detection methods.

\section{Materials and Methods}

Cell lines. The histological characteristics of the investigated cell lines are presented in Table I. A panel of 46 established human cancer cell lines were cultured in vitro, including 12 liver cancer cell lines (Hep3B, HepG2, HLE, HLF, Huh-1, Huh-7, JHH-2, JHH-5, JHH-6, JHH-7, Li-7, and PLC/PRF/5), 5 CCA lines (HuCCT-1, Huh-28, RBE, TKKK, and TFK-1), 12 pancreatic cancer lines (KP-2, KP-3, KP-3L, PANC-1, PK-1, PK-8, PK-9, QGP-1, S2-CP8, S2-VP10, SUIT-2, and T3M4), 4 oesophageal squamous cell carcinoma lines (KYSE180, KYSE30, KYSE850, and KYSE960), 4 oesophageal adenocarcinoma lines (OACM5.1C, OE19, OE33, and SK-GT-4), 5 gastric cancer lines (GCIY, MKN1, MKN45, MKN7, and MKN74), and 5 colon cancer cell lines (CACO-2, CCK-81, COLO-320, and $\mathrm{CW}-2$ ). Three primary cell lines derived from healthy human tissue served as controls: healthy hepatocytes (hNHeps), colon epithelial cells (HCoEpic), and fetal pancreatic cells (2C6). The HepG2 line was thought to be a hepatocellular carcinoma. However, there was a report that this cell line was derived from a hepatoblastoma. Therefore, we performed short tandem repeat profiling (BEX Company; Tokyo, Japan) to authenticate the HepG2 cell line (17). As a result, the HepG2 cells were confirmed to be identical to those reported in ExPASy (Expert Protein Analysis System, Swiss Institute of Bioinformatics portal) and were treated as hepatoblastoma cells. Ethical approval for experiments was not required because the cell lines are commonly available for purchase. All tested cell lines were obtained from the American Type Culture Collection (Rockville, MD, USA), Japanese Cancer Research Resources Bank (Tokyo, Japan), Institute of Physical and Chemical Research (Saitama, Japan), DS Pharma Biomedical (Osaka, Japan), Cosmo Bio Company (Tokyo, Japan), Institute of Development Aging and Cancer (Miyagi, Japan), Lonza Japan (Tokyo, Japan), and European Collection of Authenticated Cell Cultures (Public Health England, Salisbury, UK).

All cell lines underwent 1 or 2 passages after acquisition to increase cell numbers and were then stored at $-80^{\circ} \mathrm{C}$. The cells were thawed when ready for use, and DNA extraction was performed after 2 passages. Therefore, each cell line used in this study was unstimulated and had undergone less than 5 passages.

Cell culture. The cell lines were grown in their corresponding media and additives and were incubated with $5 \% \mathrm{CO}_{2}$ at $37^{\circ} \mathrm{C}$. MKN1, MKN7, MKN45, MKN74, Li-7, HuCCT1, Huh28, RBE, TFK-1, OE19, OE33, OACM5.1C, SK-GT-4, KP-2, KP-3, KP-3L, PK-1,
Table I. Characteristics of 49 cell lines evaluated for point mutations in the telomerase reverse transcriptase gene promoter.

\begin{tabular}{|c|c|c|}
\hline Cell line & Histology & Sex of donor \\
\hline \multicolumn{3}{|c|}{ Extrahepatic bile duct } \\
\hline TFK-1 & Papillary adenocarcinoma & $\mathrm{M}$ \\
\hline \multicolumn{3}{|c|}{ Intrahepatic bile duct } \\
\hline HuCCT1 & $\begin{array}{l}\text { Moderately differentiated } \\
\text { adenocarcinoma }\end{array}$ & M \\
\hline Huh28 & Cholangiocarcinoma & $\mathrm{F}$ \\
\hline RBE & Cholangiocarcinoma & $\mathrm{F}$ \\
\hline TKKK & Cholangiocarcinoma & M \\
\hline \multicolumn{3}{|l|}{ Large intestine } \\
\hline CACO-2 & Adenocarcinoma & M \\
\hline CCK-81 & Adenocarcinoma & $\mathrm{F}$ \\
\hline COLO-320 & Adenocarcinoma & $\mathrm{F}$ \\
\hline $\mathrm{CW}-2$ & Adenocarcinoma & $\mathrm{F}$ \\
\hline HCoEpic & Control epithelial cells & Unspecified \\
\hline \multicolumn{3}{|l|}{ Liver } \\
\hline Нер3В & Carcinoma & M \\
\hline HepG2 & Hepatoblastoma & M \\
\hline HLE & Undifferentiated carcinoma & M \\
\hline HLF & Undifferentiated carcinoma & M \\
\hline hNHeps & Control hepatocytes & Unspecified \\
\hline Huh-1 & Carcinoma & M \\
\hline Huh-7 & Well-differentiated carcinoma & M \\
\hline JHH-2 & Carcinoma & M \\
\hline JHH-5 & Carcinoma & $\mathrm{M}$ \\
\hline JHH-6 & Undifferentiated carcinoma & $\mathrm{F}$ \\
\hline JHH-7 & Carcinoma & M \\
\hline Li-7 & Carcinoma & M \\
\hline $\mathrm{PLC} / \mathrm{PRF} / 5$ & Carcinoma & M \\
\hline \multicolumn{3}{|l|}{ Oesophagus } \\
\hline KYSE180 & Well-differentiated squamous cell carcino & oma \\
\hline KYSE30 & Well-differentiated squamous cell carcino & oma \\
\hline KYSE850 & $\begin{array}{l}\text { Moderately differentiated } \\
\text { squamous cell carcinoma }\end{array}$ & M \\
\hline KYSE960 & $\begin{array}{l}\text { Moderately differentiated } \\
\text { squamous cell carcinoma }\end{array}$ & M \\
\hline OACM5.1C & Adenocarcinoma & $\mathrm{F}$ \\
\hline OE19 & Adenocarcinoma & M \\
\hline OE33 & Adenocarcinoma & $\mathrm{F}$ \\
\hline SK-GT-4 & Adenocarcinoma & M \\
\hline \multicolumn{3}{|l|}{ Pancreas } \\
\hline $2 \mathrm{C} 6$ & $\begin{array}{l}\text { Human line derived from } \\
\text { embryonic pancreas }\end{array}$ & Unspecified \\
\hline KP-2 & $\begin{array}{l}\text { Moderately differentiated } \\
\text { tubular adenocarcinoma }\end{array}$ & $\mathrm{F}$ \\
\hline KP-3 & Adenosquamous carcinoma & M \\
\hline KP-3L & Adenosquamous carcinoma & $\mathrm{M}$ \\
\hline PANC-1 & Ductal adenocarcinoma & M \\
\hline PK-1 & Ductal adenocarcinoma & Unspecified \\
\hline PK-8 & Carcinoma & Unspecified \\
\hline PK-9 & Ductal adenocarcinoma & M \\
\hline QGP-1 & Islet cell carcinoma & M \\
\hline S2-CP8 & Ductal adenocarcinoma & M \\
\hline S2-VP10 & Ductal adenocarcinoma & M \\
\hline SUIT-2 & $\begin{array}{l}\text { Moderately differentiated } \\
\text { tubular adenocarcinoma }\end{array}$ & M \\
\hline T3M4 & Ductal adenocarcinoma & M \\
\hline \multicolumn{3}{|l|}{ Stomach } \\
\hline GCIY & Adenocarcinoma & $\mathrm{F}$ \\
\hline MKN1 & Adenosquamous carcinoma & M \\
\hline MKN45 & Poorly differentiated adenocarcinoma & $\mathrm{F}$ \\
\hline MKN7 & Differentiated adenocarcinoma & M \\
\hline MKN74 & Moderately differentiated adenocarcinon & M \\
\hline
\end{tabular}

F: Female; M: male. 
PK-8, PK-9, PANC-1, QGP-1, COLO-320, and CW-2 cells were grown in Roswell Park Memorial Institute (RPMI 1640; FUJIFILM Corp.; Tokyo, Japan) supplemented with $10 \%$ foetal bovine serum (FBS; Corning, NY, USA) and $100 \mathrm{U} / \mathrm{ml}$ penicillin (Thermo Fisher Scientific; Waltham, MA, USA). SUIT- 2 and CCK-81 cells were grown in minimal essential medium (MEM; FUJIFILM Corp.) supplemented with $10 \%$ FBS and $100 \mathrm{U} / \mathrm{ml}$ penicillin. Hep3B and HepG2 cells were grown in MEM supplemented with 10\% FBS and $1 \%$ MEM non-essential amino acids solution (NEAA; Thermo Fisher Scientific). CACO-2 cells were grown in MEM supplemented with $1 \%$ NEAA, 20\% FBS, and $100 \mathrm{U} / \mathrm{ml}$ penicillin. JHH-5, JHH-6, and JHH-7 cells were grown in Williams' Medium E (Sigma-Aldrich Corp., St. Louis, MO, USA) supplemented with $10 \%$ FBS and 100 $\mathrm{U} / \mathrm{ml}$ penicillin. JHH-2 cells were grown in Williams' Medium E supplemented with $2 \%$ FBS and $100 \mathrm{U} / \mathrm{ml}$ penicillin. Huh-1, Huh7, PLC/PRF/5, HLE, TKKK, S2-CP8 and S2-VP10 cells were grown in Dulbecco's Modified Eagle's Medium (DMEM; Thermo Fisher Scientific) supplemented with $10 \% \mathrm{FBS}$ and $100 \mathrm{U} / \mathrm{ml}$ penicillin KYSE180, KYSE850, and KYSE960 cells were grown in a 1:1 mixture of RPMI 1640 and Ham's F12 medium (FUJIFILM Corp.) containing 2\% FBS and $100 \mathrm{U} / \mathrm{ml}$ penicillin. HLF cells were grown in DMEM with 5\% FBS and $100 \mathrm{U} / \mathrm{ml}$ penicillin. KYSE30 cells were grown in DMEM with 2\% FBS and $100 \mathrm{U} / \mathrm{ml}$ penicillin. T3M4 cells were grown in Ham's F10 medium (FUJIFILM Corp.) supplemented with $10 \%$ FBS and $100 \mathrm{U} / \mathrm{ml}$ penicillin. The hNHeps cells were grown using a CS-C medium kit (DS Pharma Biomedical; Osaka, Japan) in accordance with the manufacturer's protocol. The 2C6 cells were grown in Ham's F10 medium supplemented with 5\% FBS, 10\% newborn calf serum (Thermo Fisher Scientific), 2.5\% horse serum (Thermo Fisher Scientific), and $100 \mathrm{U} / \mathrm{ml}$ penicillin. The HCoEpiC cells were grown in Colonic Epithelial Cell Medium (SienCell Research Laboratories; Carlsbad, CA, USA) supplemented with Colonic Epithelial Cell Growth Supplement (SienCell Reasearch Laboratories).

DNA extraction. Genomic DNA was isolated using the PureLink Genomic DNA kit (Thermo Fisher Scientific) in accordance with the manufacturer's protocol. DNA concentration and purity were determined using a NanoDrop spectrophotometer (Thermo Fisher Scientific). DNA extraction of the various cell lines was performed after 2 passages.

Quantification of TERT promoter mutations by digital PCR. The $\mathrm{dPCR}$ analysis was performed with isolated genomic DNA using the QuantStudio $^{\mathrm{TM}}$ 3D digital PCR system (Thermo Fisher Scientific) with custom TaqMan primers and probes labelled with 6carboxyfluorescein (FAM) and 2'-chloro-7'-phenyl-1,4-dichloro-6carboxyfluorescein (VIC; Thermo Fisher Scientific) for detection of TERT C228T (-124 bp) and TERT C250T (-146 bp) promoter mutations. The Huh-7 cell line was used as a known positive DNA control, and Hep3B cells were the negative control in each dPCR run. Each dPCR reaction was performed using $7.5 \mu \mathrm{l}$ of QuantStudio $^{\text {TM }}$ 3D digital PCR master mix, $0.375 \mu$ l of TaqMan primer/probe for each TERT mutation, $6.125 \mu \mathrm{l}$ of water, and $10 \mathrm{ng}$ of DNA in a final reaction volume of $14.5 \mu \mathrm{l}$; the mixture was loaded onto a QuantStudio ${ }^{\mathrm{TM}}$ 3D digital PCR chip (Thermo Fisher Scientific). PCR amplification was performed using the Applied Biosystems ProFlex PCR System under the following conditions: one cycle at $96^{\circ} \mathrm{C}$ for $10 \mathrm{~min}$ followed by 39 cycles of $98^{\circ} \mathrm{C}$ for 30 $\mathrm{s}$ and $60^{\circ} \mathrm{C}$ for $2 \mathrm{~min}$.

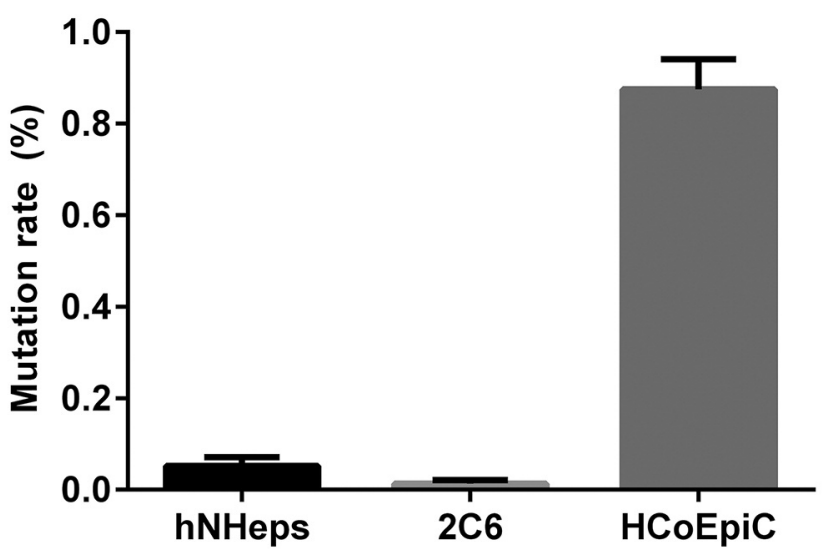

Figure 1. Mutation rates are shown for the C228T TERT promoter point mutation in three types of healthy control cells. Among the three healthy control cell lines, HCoEpiC had the highest frequency of TERT promoter point mutations.

Wild-type and mutant alleles were analysed using QuantStudio 3D AnalysisSuite software (Thermo Fisher Scientific). For each dPCR experiment, the mean number of copies per partition and the number of estimated copies per total reaction volume for the unknown samples were calculated. For each run, at least one negative template control, a wild-type positive control, and rare mutation positive controls were included. Each dPCR experiment was performed three times for each cell line on different days under the same PCR conditions.

Statistical analysis. Results are expressed as the mean \pm standard deviation (SD). All statistical analyses were performed using GraphPad Prism 6 software (GraphPad Software; La Jolla, CA, USA). Significant differences were determined between the reference cells (HCoEpiC) and each cell line by Student's $t$-test. $p$ Values less than 0.05 were considered significant.

\section{Results}

Prevalence of C228T TERT promoter mutations using dPCR. The presence of the C228T or C250T mutations within the TERT promoter region was analysed in cell lines derived from solid tumours and healthy human tissues as shown in Table I. DPCR was first performed on healthy control cell lines to detect the mutations. HCoEpic cells had the highest percentage of TERT promoter point mutations among the healthy human control cell lines, which included 2C6 and hNHeps cells (Figure 1); thus, this cell line was used as the control for comparisons with the cancer cell lines.

DPCR was used to compare the cancer cell lines with HCoEpic control cells to detect the C228T mutation in the TERT promoter (Figure 2, Figure 3 and Figure 4). The mutation was detected in 9 out of 12 liver cancer cell lines, including JHH-6, JHH-5, Li-7, HepG2, Huh-7, HLE, JHH7, HLF, and JHH-2. No significant differences were observed 


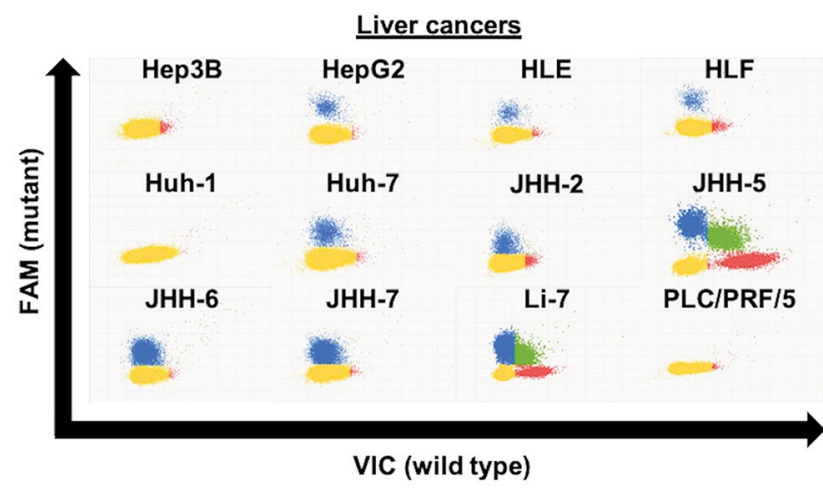

Figure 2. The C228T TERT promoter mutation detected by dPCR in liver cancer cells. The results of $\mathrm{APCR}$ for DNA extracted from liver cancer cell lines are plotted. Signals from FAM (C228T mutation; blue) and VIC (wild type; red) dyes are plotted on the $x$ - and y-axis, respectively. Yellow clusters represent wells that were not amplified (negative calls), while green clusters indicate wells that contained both VIC and FAM signals. Among the 12 liver cancer cell lines, 9 showed a high frequency of TERT promoter point mutations. dPCR: Digital polymerase chain reaction; FAM: 6-carboxyfluorescein; HCC: hepatocellular carcinoma; VIC: 2'-chloro-7'-phenyl-1,4-dichloro-6carboxyfluorescein.

between the control cells and the remaining three liver cancer cell lines (Hep3B, Huh-1, and PLC/PRF/5; Figure 3). Compared with those of the HCoEpic cells, the mutation rates were significantly higher in the following liver cancer cell lines: JHH-5 (51.2\%-84.1\%, $p=0.011)$, JHH-6 (71.5\%$74.5 \%, p<0.001)$, Li-7 (43.4\%-70.0\%, $p=0.0013)$, Huh-7 $(50.8 \%-51.7 \%, p<0.001)$, HLE $(49.4 \%-51.4 \%, p=0.032)$, HepG2 (50.0\%-51.1\%, $p<0.001)$, JHH-7 (38.4\%-47.9\%, $p<0.001)$, HLF (33.9\%-35.0\%, $p=0.01)$, and JHH-2 (24.5\%$26.3 \%, p=0.018$ ) (Figure 3). The mutant allele abundance of the remaining cell lines is shown in Figure 4; compared with that of control cells, the mutation rate was not significantly higher in cancer cell lines derived from the oesophagus, intrahepatic bile duct, large intestine, stomach, or pancreas.

Prevalence of C250T TERT promoter mutations using dPCR. As with the C228T mutation, the HCoEpiC cell line had the highest mutation rate for the C250T TERT mutation among the three healthy control lines tested and was used as the control for assessing the presence of this mutation in the cancer cells (Figure 5). Among oesophageal cancer cell lines, the C250T mutation was observed in KYSE850 cells (Figure 6 ), and the mutation rate in this line was significantly higher than that in the control cells ( $p=0.0012$; Figure 7). With the exception of SK-GT-4, which had a TERT promoter point mutation rate of $0.1433 \%$, the remaining oesophageal carcinoma cell lines (KYSE30, KYSE180, KYSE960, OE19, OE-33, and OACM5.1C) had a TERT promoter point

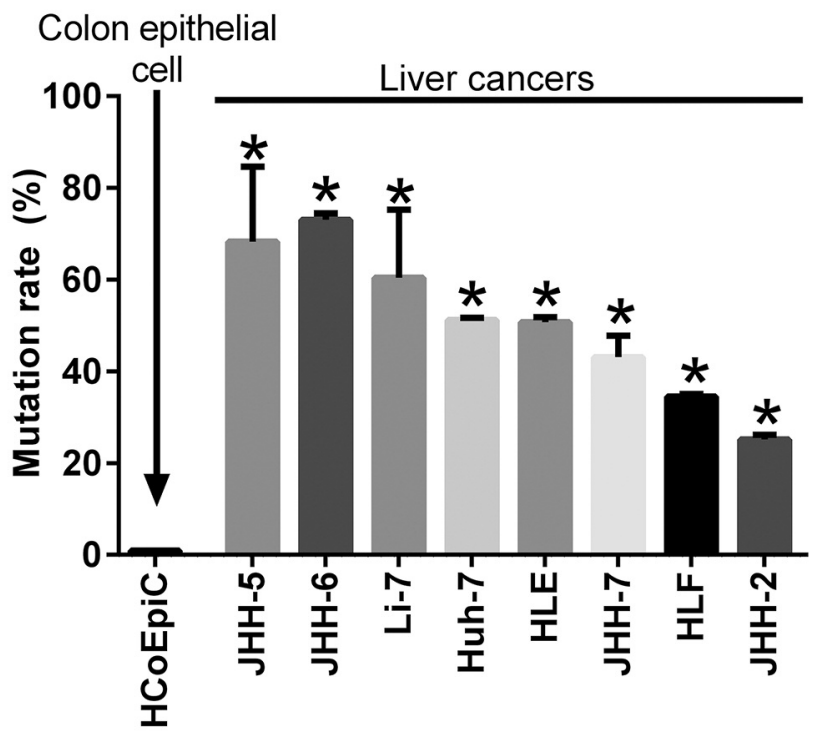

Figure 3. The figure compares nine liver cancer cell lines in which TERT promoter point mutations were frequently detected with HCoEpiC control cells. The mutation rates for all of the nine liver cancer cell lines were significantly different compared with the mutation rate for HCoEpiC cells. Values represent mean $\pm S D ; * p<0.05$ vs. HCoEpiC control cells.

mutation rate of $<0.1 \%$, which was not significantly different from the control cells (Figure 8). The mutant allele abundance for the cell lines is shown in Figure 8. The mutation rates were not significantly different between the control cells and the hepatobiliary, pancreatic, gastric, or colonic cancer cell lines.

\section{Discussion}

TERT promoter mutations have been found in numerous cancers, but few studies have comprehensively examined large numbers of hepatobiliary and pancreatic cell lines to detect these mutations. Although large collections of cell lines, such as the NCI-60 panel (18), are available and have been characterized, the collection of hepatobiliary, pancreatic, and upper gastrointestinal cancer-derived cell lines is markedly smaller compared with that of other common tumour types, and these cells have been poorly characterized. Therefore, in this experiment, we evaluated cell lines from gastrointestinal malignancies that were not part of the NCI-60 panel collection and did not overlap with published literature.

In the present study, we used $\mathrm{dPCR}$ to analyse the presence of two TERT promoter mutations, C228T and C250T, in hepatobiliary, pancreatic, and gastrointestinal cancer cell lines. We detected the presence of C228T mutations in 9 of 12 liver cancer cell lines, but not in the cell 


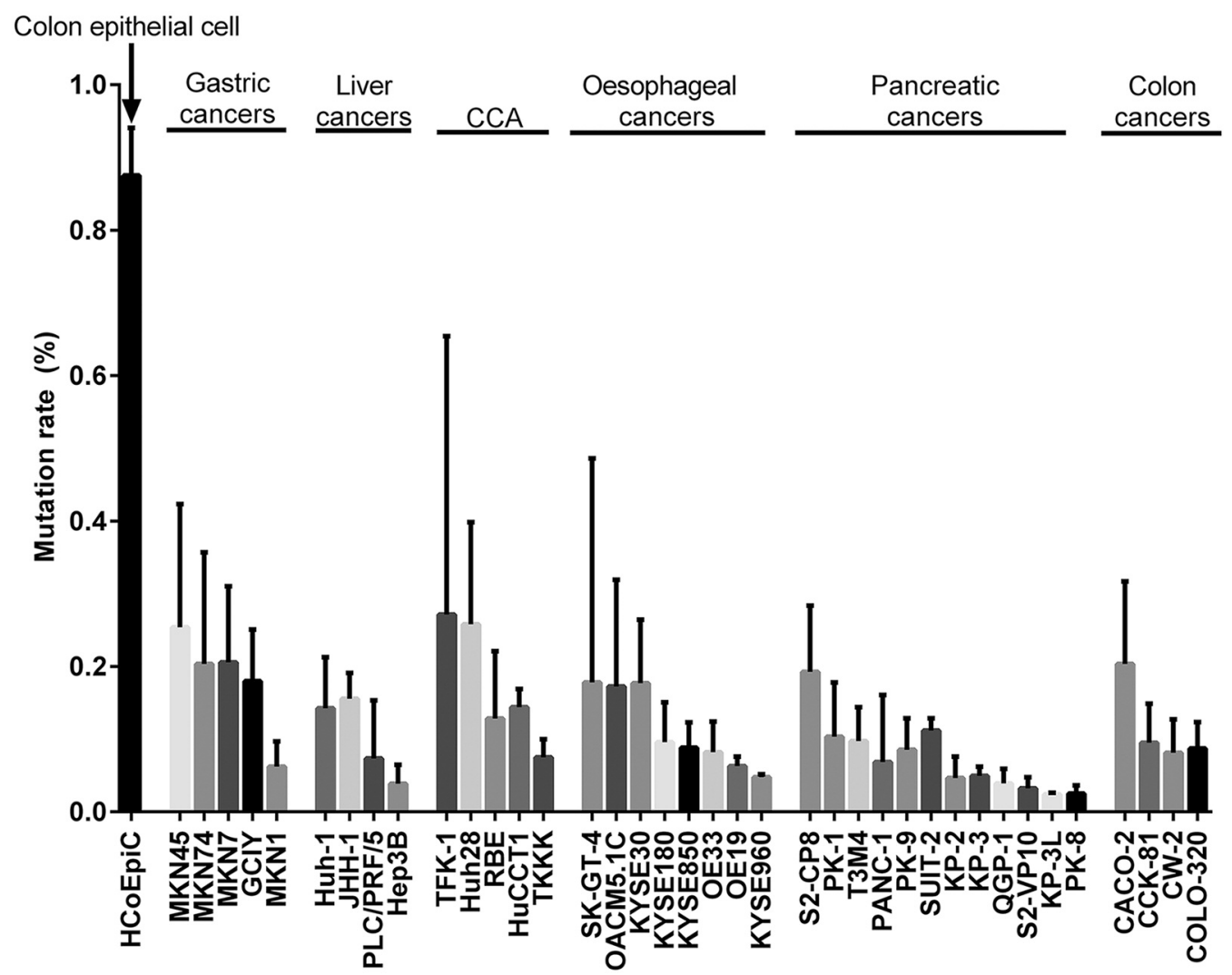

Figure 4. The mutation rate of HCoEpiC control cells was compared with those of 37 cancer cell lines, excluding the liver cancer lines described in Figure 3. These cell lines demonstrated a low frequency of TERT promoter point mutations. There was no significant difference in mutation rates between any of the cancer cell lines and the rate for HCoEpiC cells.

lines derived from pancreatic, intrahepatic bile duct, oesophageal, stomach, or colon cancers. The C250T mutation was only detected in 1 of 8 oesophageal cell lines (KYSE850) and was not detected in any of the remaining cell lines. Our results are consistent with those of another study that examined the presence of C228T/C250T mutations in a large panel of cell lines in which a high degree of variability in mutation status was observed depending on the cell line of origin (19). Furthermore, our results greatly expand on this study because of the inclusion of liver cell lines as well as the inclusion of numerous additional gastrointestinal, intrahepatic bile duct, oesophageal, and pancreatic lines.

Consistent with our results, the C228T mutation is frequently observed in patients with HCC (19). A previous study reported that TERT promoter point mutations were less frequent in HBV-positive HCC (20). In our study, there were $4 \mathrm{HBV}$-positive liver cancer cell lines, and 1 of these 4 lines showed a high frequency of TERT promoter point mutations, whereas the other 3 lines showed a low frequency of mutations. In our study, C228T TERT promoter point mutations were found in $75 \%$ of the liver cancer cell lines.

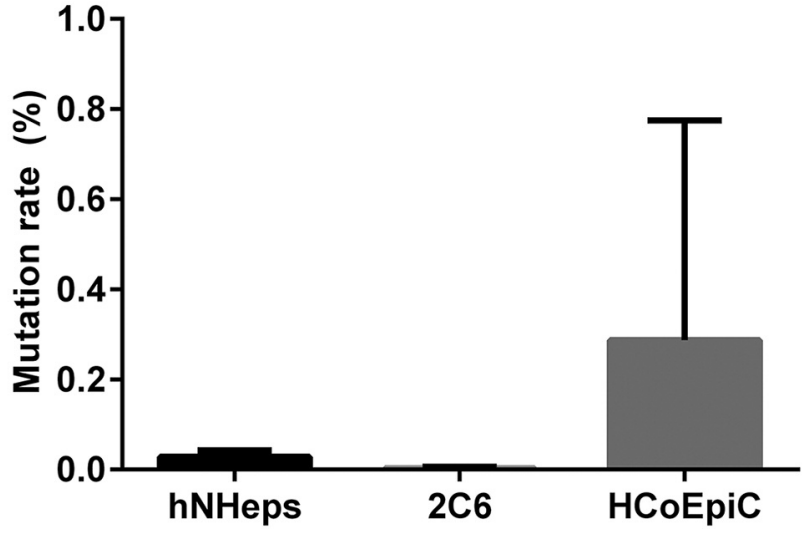

Figure 5. Mutation rates are shown for the C250T TERT promoter point mutation in three types of healthy control cells. Among the three healthy control cell lines, HCoEpiC cells had the highest frequency of this TERT promoter point mutation.

Another study reported $43.3 \%$ positivity for TERT promoter mutations in HCC, although this latter study evaluated human HCC clinical samples (21). DPCR is more accurate 


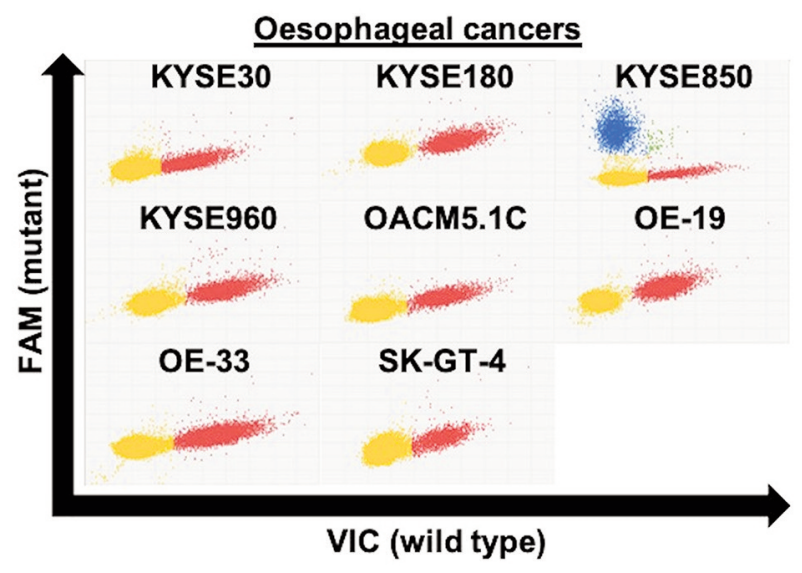

Figure 6. The C250T TERT promoter mutation detected by $d P C R$ in oesophageal carcinoma cell lines. The results of $d P C R$ for DNA extracted from oesophageal carcinoma cell lines are plotted. Signals from FAM (C250T mutation; blue) and VIC (wild type; red) dyes are plotted on the $x$ - and $y$-axis, respectively. Yellow clusters represent wells that were not amplified (negative calls). Among the eight oesophageal cancer cell lines, only KYSE850 showed a high frequency of TERT promoter point mutations. PPCR: Digital polymerase chain reaction; FAM: 6-carboxyfluorescein; VIC: 2'-chloro-7'-phenyl-1,4-dichloro-6carboxyfluorescein.

for quantifying relative abundance, while being less sensitive for absolute quantification because of the smaller reaction volumes compared with those of real-time PCR (22). Therefore, dPCR may be preferable to conventional real-time PCR for detecting TERT promoter point mutations.

Expression of TERT is critical for reactivation of telomerase, which plays an important role in the development and proliferation of cancer cells through telomere protection and avoidance of senescence (23). TERT promoter mutation rates vary significantly among human malignancies depending on their histological type and cellular origin (24). Our results are consistent with clinical data demonstrating the variability in TERT mutation rates among different types of cancers (25-28). For example, glioblastoma, malignant melanoma, and urothelial bladder cancers exhibit a high mutation rate, while thyroid cancer, hepatocellular carcinoma, and urinary carcinoma have an intermediate level; other tumours, such as those from the lung, breast, gastrointestinal tract, prostrate, and kidney, are characterized by a low mutation rate or lack of TERT mutations (25-28).

Although TERT promoter mutations have an important role in tumourigenesis and appear to have promise as biomarkers or prognostic factors (29-32), TERT promoter regulation is likely to be a multifactorial process involving genetic, epigenetic, transcriptional, and posttranscriptional factors (33). A comprehensive analysis of 31 cancer types found TERT expression in $73 \%$ of tumours; genetic

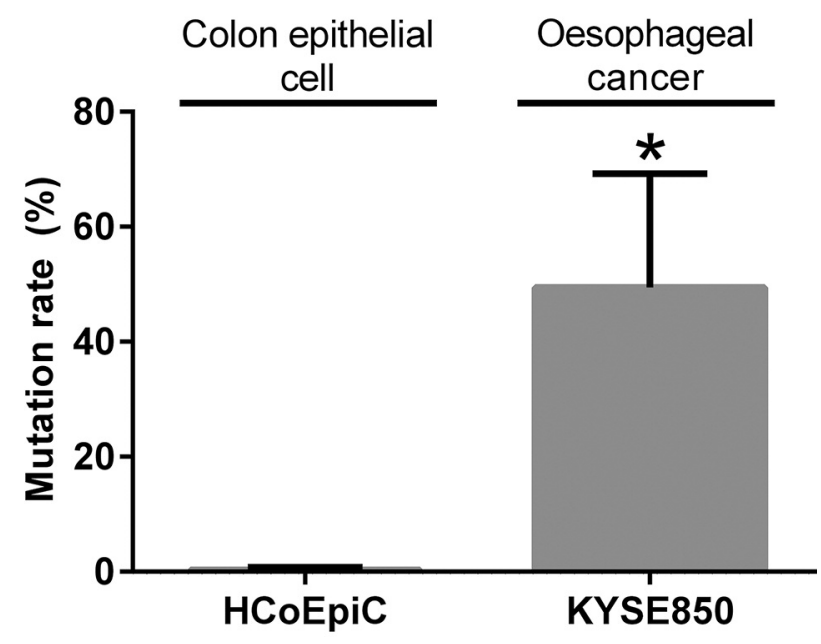

Figure 7. Mutant allele (C250T TERT) abundance expressed as the percent mutation rate in HcoEpiC control cells versus the KYSE850 oesophageal carcinoma line. The mutation rate was significantly higher in KYSE850 cells compared with that in HCoEpiC cells. Values represent mean $\pm S D ; * p<0.05$ vs. HCoEpiC control cells.

alterations as well as promoter methylation were predictive of telomerase activity (12). Furthermore, TERT expression was undetectable in an additional $22 \%$ or more of the tumours studied.

There are several limitations in our study. First, the concentration of DNA extracted from the HCoEpiC control cells was slightly lower than that of other cancer cell lines. This caused the total gene copy numbers to be lower, which resulted in a slightly higher relative percentage. For example, the C228T mutation rate in 2C6 cells, which had the lowest mutation frequency among the control cells, was $0.013 \%$ (0.007\%-0.021\%) compared with $0.875 \%$ (0.8280\%-0.950\%) in the HCoEpiC line. However, when compared with the real number of FAMs, 0.330 copies/ $\mu$ l (range=0.150-0.447 copies $/ \mu \mathrm{l}$ ) for $\mathrm{HCoEpiC}$ was less than 0.419 copies $/ \mu 1$ (range $=0.228-0.676 \mathrm{copies} / \mu \mathrm{l})$ for $2 \mathrm{C} 6$. For this reason, the mutation rate of $\mathrm{HCoEpiC}$ was higher. Therefore, the values for mutation rates of HCoEpiC appear to be different in Figure 1 and Figure 5. Second, this study lacks experiments that analyse the association between TERT point mutations and function in each cell line. Further experiments are needed to evaluate the relationship between TERT mutation rates, telomerase length, and telomerase activity in these cells. Third, we did not evaluate TERT mutations in human clinical specimens. However, it will be desirable to conduct confirmatory studies to determine the consistency of the results of these basic experiments using human clinical samples in the future.

In conclusion, we have comprehensively analysed the presence of TERT promoter point mutations in liver cancer 


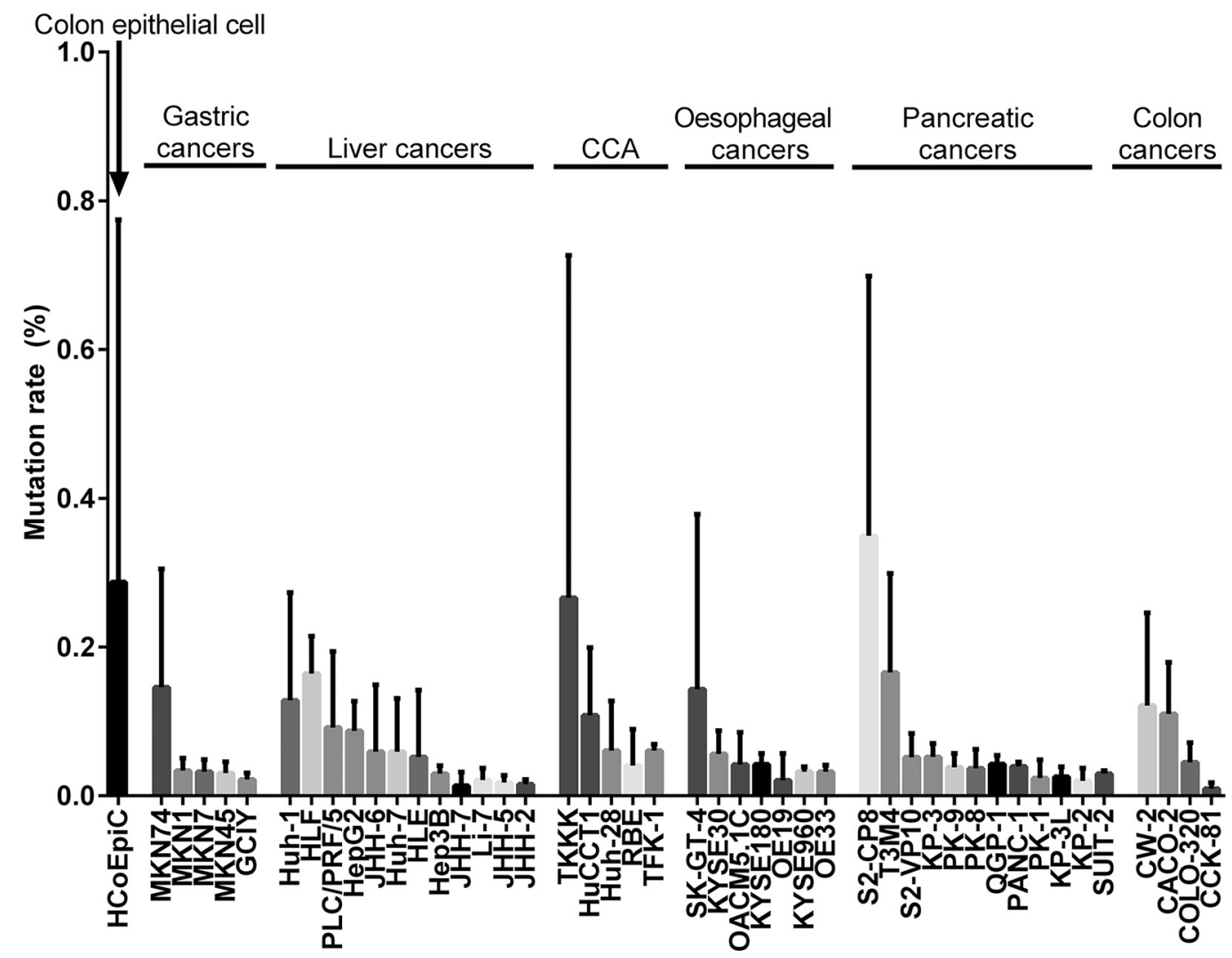

Figure 8. The C250T TERT mutation rates are shown for HcoEpiC control cells versus all other cell lines except KYSE850. There was no significant difference in the mutation rate between the HCoEpiC control cells and any of the gastric cancer, liver cancer, CCA, oesophageal cancer (except KYSE850), pancreatic cancer, or colon cancer cell lines.

cell lines, CCA, and gastrointestinal cancer cell lines using dPCR. By examining the presence or absence of the C228T and C250T TERT promoter point mutations in various cancer lines, we found that the C228T TERT promoter point mutation was specific for liver cancer lines. These data are expected to contribute to future research, including measurements of chemical biomarkers and elucidation of the oncogenic mechanisms.

\section{Conflicts of Interest}

The Authors declare that they have no competing interests in relation to this study.

\section{Authors' Contributions}

MH and TM designed the experiments. KF, TM, RN, SF, TK, DN, $\mathrm{NF}, \mathrm{HY}, \mathrm{HKa}, \mathrm{JT}, \mathrm{HKo}, \mathrm{KT}$, and HSM performed the experiments and analysed the data. TM performed final drafting and writing of the manuscript. YM contributed to the reanalysis of data for comparison of mutation rates of TERT point mutations. SF and MO contributed to drafting of the manuscript. All Authors have read and approved the final version of the manuscript.

\section{Acknowledgements}

The Authors thank Ms. Kayo Hirose, Ms. Megumi Okamura, Ms. Keiko Fujikawa, Ms. Mari Yamada, and Ms. Fuyuko Kokado for their skilful technical assistance. The Authors would also like to thank Lisa Bolin, Ph.D., from Edanz (https://jp.edanz.com/ac) for editing a draft of this manuscript.

\section{References}

1 Smekalova EM, Shubernetskaya OS, Zvereva MI, Gromenko EV, Rubtsova MP and Dontsova OA: Telomerase RNA biosynthesis and processing. Biochemistry (Mosc) 77(10): 1120-1128, 2012. PMID: 23157292. DOI: 10.1134/S0006297912100045

2 Kim NW, Piatyszek MA, Prowse KR, Harley CB, West MD, Ho PL, Coviello GM, Wright WE, Weinrich SL and Shay JW: Specific association of human telomerase activity with immortal cells and cancer. Science 266(5193): 2011-2015, 1994. PMID: 7605428. DOI: $10.1126 /$ science.7605428

3 Greider CW: Telomerase activity, cell proliferation, and cancer. Proc Natl Acad Sci U.S.A. 95(1): 90-92, 1998. PMID: 9419332. DOI: $10.1073 /$ pnas.95.1.90

4 Daniel M, Peek GW and Tollefsbol TO: Regulation of the human catalytic subunit of telomerase (hTERT). Gene 498(2): 
135-146, 2012. PMID: 22381618. DOI: 10.1016/j.gene.2012. 01.095

5 Lewis KA and Tollefsbol TO: Regulation of the telomerase reverse transcriptase subunit through epigenetic mechanisms. Front Genet 7: 83, 2016. PMID: 27242892. DOI: 10.3389/fgene. 2016.00083

6 Ramlee MK, Wang J, Toh WX and Li S: Transcription regulation of the human telomerase reverse transcriptase (hTERT) gene. Genes (Basel) 7(8): 50, 2016. PMID: 27548225. DOI: 10.3390/ genes 7080050

7 Jie MM, Chang X, Zeng S, Liu C, Liao GB, Wu YR, Liu CH, $\mathrm{Hu}$ CJ, Yang SM and Li XZ: Diverse regulatory manners of human telomerase reverse transcriptase. Cell Commun Signal 17(1): 63, 2019. PMID: 31186051. DOI: 10.1186/s12964-0190372-0

8 Bell RJ, Rube HT, Xavier-Magalhães A, Costa BM, Mancini A, Song JS and Costello JF: Understanding TERT promoter mutations: A common path to immortality. Mol Cancer Res 14(4): 315-323, 2016. PMID: 26941407. DOI: 10.1158/15417786.MCR-16-0003

9 Huang FW, Hodis E, Xu MJ, Kryukov GV, Chin L and Garraway LA: Highly recurrent TERT promoter mutations in human melanoma. Science 339(6122): 957-959, 2013. PMID: 23348506. DOI: $10.1126 /$ science. 1229259

10 Horn S, Figl A, Rachakonda PS, Fischer C, Sucker A, Gast A, Kadel S, Moll I, Nagore E, Hemminki K, Schadendorf D and Kumar R: TERT promoter mutations in familial and sporadic melanoma. Science 339(6122): 959-961, 2013. PMID: 23348503. DOI: $10.1126 /$ science. 1230062

11 In der Stroth L, Tharehalli U, Günes C and Lechel A: Telomeres and telomerase in the development of liver cancer. Cancers (Basel) 12(8): 2048, 2020. PMID: 32722302. DOI: 10.3390/ cancers 12082048

12 Killela PJ, Reitman ZJ, Jiao Y, Bettegowda C, Agrawal N, Diaz LA Jr, Friedman AH, Friedman H, Gallia GL, Giovanella BC, Grollman AP, He TC, He Y, Hruban RH, Jallo GI, Mandahl N, Meeker AK, Mertens F, Netto GJ, Rasheed BA, Riggins GJ, Rosenquist TA, Schiffman M, Shih IeM, Theodorescu D, Torbenson MS, Velculescu VE, Wang TL, Wentzensen N, Wood LD, Zhang M, McLendon RE, Bigner DD, Kinzler KW, Vogelstein B, Papadopoulos N and Yan H: TERT promoter mutations occur frequently in gliomas and a subset of tumors derived from cells with low rates of self-renewal. Proc Natl Acad Sci U.S.A. 110(15): 60216026, 2013. PMID: 23530248. DOI: 10.1073/pnas.1303607110

13 Heidenreich B, Rachakonda PS, Hemminki K and Kumar R: TERT promoter mutations in cancer development. Curr Opin Genet Dev 24: 30-37, 2014. PMID: 24657534. DOI: 10.1016/ j.gde.2013.11.005

14 Wang K, Wang RL, Liu JJ, Zhou J, Li X, Hu WW, Jiang WJ and Hao NB: The prognostic significance of hTERT overexpression in cancers: A systematic review and meta-analysis. Medicine (Baltimore) 97(35): e11794, 2018. PMID: 30170373. DOI: 10.1097/MD.0000000000011794

15 Hirai M, Kinugasa H, Nouso K, Yamamoto S, Terasawa H, Onishi Y, Oyama A, Adachi T, Wada N, Sakata M, Yasunaka T, Onishi H, Shiraha H, Takaki A and Okada H: Prediction of the prognosis of advanced hepatocellular carcinoma by TERT promoter mutations in circulating tumor DNA. J Gastroenterol Hepatol 36(4): 1118-1125, 2021. PMID: 32830343. DOI: $10.1111 /$ jgh. 15227
16 Zhao Y, Gao Y, Chen Z, Hu X, Zhou F and He J: Low frequency of TERT promoter somatic mutation in 313 sporadic esophageal squamous cell carcinomas. Int J Cancer 134(2): 493-494, 2014. PMID: 23818232. DOI: $10.1002 / \mathrm{ijc} .28360$

17 López-Terrada D, Cheung SW, Finegold MJ and Knowles BB: Hep G2 is a hepatoblastoma-derived cell line. Hum Pathol 40(10): 1512-1515, 2009. PMID: 19751877. DOI: 10.1016/ j.humpath.2009.07.003

18 Abaan OD, Polley EC, Davis SR, Zhu YJ, Bilke S, Walker RL, Pineda M, Gindin Y, Jiang Y, Reinhold WC, Holbeck SL, Simon RM, Doroshow JH, Pommier Y and Meltzer PS: The exomes of the NCI-60 panel: a genomic resource for cancer biology and systems pharmacology. Cancer Res 73(14): 4372-4382, 2013. PMID: 23856246. DOI: 10.1158/0008-5472.CAN-12-3342

19 Huang FW, Bielski CM, Rinne ML, Hahn WC, Sellers WR, Stegmeier F, Garraway LA and Kryukov GV: TERT promoter mutations and monoallelic activation of TERT in cancer. Oncogenesis 4: e176, 2015. PMID: 26657580. DOI: 10.1038/ oncsis.2015.39

20 Kawai-Kitahata F, Asahina Y, Tanaka S, Kakinuma S, Murakawa M, Nitta S, Watanabe T, Otani S, Taniguchi M, Goto F, Nagata H, Kaneko S, Tasaka-Fujita M, Nishimura-Sakurai Y, Azuma S, Itsui Y, Nakagawa M, Tanabe M, Takano S, Fukasawa M, Sakamoto M, Maekawa S, Enomoto $\mathrm{N}$ and Watanabe $\mathrm{M}$ : Comprehensive analyses of mutations and hepatitis $\mathrm{B}$ virus integration in hepatocellular carcinoma with clinicopathological features. J Gastroenterol 51(5): 473-486, 2016. PMID: 26553052. DOI: $10.1007 / \mathrm{s} 00535-015-1126-4$

21 Lombardo D, Saitta C, Giosa D, Di Tocco FC, Musolino C, Caminiti G, Chines V, Franzè MS, Alibrandi A, Navarra G, Raimondo G and Pollicino T: Frequency of somatic mutations in TERT promoter, TP53 and CTNNB1 genes in patients with hepatocellular carcinoma from Southern Italy. Oncol Lett 19(3): 2368-2374, 2020. PMID: 32194736. DOI: 10.3892/ol.2020.11332

22 Quan PL, Sauzade M and Brouzes E: dPCR: A technology review. Sensors (Basel) 18(4): 1271, 2018. PMID: 29677144. DOI: $10.3390 / \mathrm{s} 18041271$

23 Dratwa M, Wysoczanska B, Turlej E, Anisiewicz A, Maciejewska M, Wietrzyk $\mathrm{J}$ and Bogunia-Kubik K: Heterogeneity of telomerase reverse transcriptase mutation and expression, telomerase activity and telomere length across human cancer cell lines cultured in vitro. Exp Cell Res 396(1): 112298, 2020. PMID: 32971118. DOI: 10.1016/j.yexcr.2020.112298

24 Amisaki M, Tsuchiya H, Sakabe T, Fujiwara Y and Shiota G: Identification of genes involved in the regulation of TERT in hepatocellular carcinoma. Cancer Sci 110(2): 550-560, 2019. PMID: 30447097. DOI: 10.1111/cas.13884

25 Vinagre J, Almeida A, Pópulo H, Batista R, Lyra J, Pinto V, Coelho R, Celestino R, Prazeres H, Lima L, Melo M, da Rocha AG, Preto A, Castro P, Castro L, Pardal F, Lopes JM, Santos LL, Reis RM, Cameselle-Teijeiro J, Sobrinho-Simões M, Lima J, Máximo V and Soares P: Frequency of TERT promoter mutations in human cancers. Nat Commun 4: 2185, 2013. PMID: 23887589. DOI: $10.1038 /$ ncomms 3185

26 Barthel FP, Wei W, Tang M, Martinez-Ledesma E, Hu X, Amin SB, Akdemir KC, Seth S, Song X, Wang Q, Lichtenberg T, Hu J, Zhang J, Zheng S and Verhaak RG: Systematic analysis of telomere length and somatic alterations in 31 cancer types. Nat Genet 49(3): 349-357, 2017. PMID: 28135248. DOI: 10.1038/ ng. 3781 
27 Borah S, Xi L, Zaug AJ, Powell NM, Dancik GM, Cohen SB, Costello JC, Theodorescu D and Cech TR: Cancer. TERT promoter mutations and telomerase reactivation in urothelial cancer. Science 347(6225): 1006-1010, 2015. PMID: 25722414. DOI: $10.1126 /$ science. 1260200

28 Landa I, Ganly I, Chan TA, Mitsutake N, Matsuse M, Ibrahimpasic T, Ghossein RA and Fagin JA: Frequent somatic TERT promoter mutations in thyroid cancer: higher prevalence in advanced forms of the disease. J Clin Endocrinol Metab 98(9): E1562-E1566, 2013. PMID: 23833040. DOI: 10.1210/ jc. $2013-2383$

29 Trung NT, Hoan NX, Trung PQ, Binh MT, Van Tong H, Toan NL, Bang MH and Song LH: Clinical significance of combined circulating TERT promoter mutations and miR-122 expression for screening HBV-related hepatocellular carcinoma. Sci Rep 10(1): 8181, 2020. PMID: 32424223. DOI: 10.1038/s41598-02065213-8

30 Zheng X, Zhuge J, Bezerra SM, Faraj SF, Munari E, Fallon JT

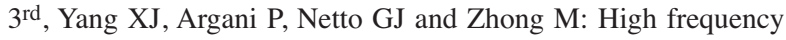
of TERT promoter mutation in small cell carcinoma of bladder, but not in small cell carcinoma of other origins. J Hematol Oncol 7: 47, 2014. PMID: 25042800. DOI: 10.1186/s13045-014-0047-7
31 Oversoe SK, Clement MS, Pedersen MH, Weber B, Aagaard NK, Villadsen GE, Grønbæk H, Hamilton-Dutoit SJ, Sorensen BS and Kelsen J: TERT promoter mutated circulating tumor DNA as a biomarker for prognosis in hepatocellular carcinoma. Scand J Gastroenterol 55(12): 1433-1440, 2020. PMID: 33103505. DOI: 10.1080/00365521.2020.1837928

32 Akuta N, Kawamura Y, Kobayashi M, Arase Y, Saitoh S, Fujiyama S, Sezaki H, Hosaka T, Kobayashi M, Suzuki Y, Suzuki F, Ikeda K and Kumada H: TERT promoter mutation in serum cell-free DNA is a diagnostic marker of primary hepatocellular carcinoma in patients with nonalcoholic fatty liver disease. Oncology 99(2): 114-123, 2021. PMID: 32998139. DOI: $10.1159 / 000510366$

33 Dogan F and Forsyth NR: Telomerase regulation: a role for epigenetics. Cancers (Basel) 13(6): 1213, 2021. PMID: 33802026. DOI: $10.3390 /$ cancers 13061213

Received October 5, 2021

Revised September 27, 2021

Accepted October 29, 2021 